\title{
Genetic Diversity of Isolates of Macrophomina phaseolina Associated with Cowpea from Brazil Semi-Arid Region
}

\author{
Fabiola Gomes-Silva ${ }^{1}$, Clebia M. A. Almeida ${ }^{2}$, Alexandre G. Silva ${ }^{2}$, Mariele P. C. Leão ${ }^{3}$, Karla P. Silva ${ }^{3}$, \\ Luciana G. Oliveira ${ }^{3}$, Márcia V. Silva ${ }^{2}$, Antonio F. $\operatorname{Costa}^{3} \&$ Vera L. M. Lima ${ }^{2}$ \\ ${ }^{1}$ Programa de Pós-Graduação em Ciências Biológicas, Universidade Federal de Pernambuco, Recife, Brazil \\ ${ }^{2}$ Departamento de Bioquímica, Universidade Federal de Pernambuco, Recife, Brazil \\ ${ }^{3}$ Instituto Agronômico de Pernambuco (IPA), Recife, Brazil \\ Correspondence: Vera L. M. Lima, Departamento de Bioquímica, Universidade Federal de Pernambuco, Av. Prof. \\ Moraes Rego, s/n, Cidade Universitária, Recife, PE, CEP: 50670-420, Brazil. Tel: 55-(81)-2126-8576. E-mail: \\ lima.vera.ufpe@gmail.com
}

Received: May 13, 2017

doi:10.5539/jas.v9n11p112
Accepted: September 13, $2017 \quad$ Online Published: October 15, 2017

URL: https://doi.org/10.5539/jas.v9n11p112

\begin{abstract}
Cowpea crops have the highest social and economic relevance to Brazil, being the food base of families mainly in the semi-arid areas of the country. Charcoal rot caused by Macrophomina phaseolina is an economically important disease of cowpea that can cause significant reductions in bean yield. This study aimed to access the genetic diversity of $M$. phaseolina isolates obtained from cowpea grown in the Pernambuco semi-arid region, by molecular analysis. Fifty-one isolates, collected from municipality of Belém do São Francisco from cowpea plants and displaying typical symptoms and signs of charcoal rot, were studied using inter-simple sequence repeat (ISSR) markers. Unweighted pair-group method using arithmetic means (UPGMA) clustering of data showed that isolates clearly differentiate into two groups. The group 1 comprises the majority of isolates and the group 2 contains two isolates, isol46 and isol47. The highest similarity index (0.9) was observed between the isolates isol22 and isol35 and the lowest similarity index (0.2) was observed between isol37 and isol46 isolates. Our results revealed that the ISSR-PCR fingerprinting patterns were useful for differentiating $M$. phaseolina isolates from $V$. unguiculata plants sampled. Therefore, genetic characterization of this fungus is of importance for the effective disease management.
\end{abstract}

Keywords: charcoal rot, ISSR markers, phytopathogenic fungi, Vigna unguiculata

\section{Introduction}

Cowpea (Vigna unguiculata L. Walp) is a very important crop to the agricultural systems in the Brazil. It is cultivated with prominence in the states of Ceará, Bahia and Piaú, in the Northeast; and Pará in the north. In both regions, the production is consumed internally, being the food base of families mainly in the semi-arid areas of the Northeast (Marinho et al., 2017). Cowpea genotypes contributes with $35.6 \%$ of the planted area and $15 \%$ of the total bean production (cowpea + common bean) in the country (FAO, 2016). Cowpea production is a significant economic activity in the Brazilian Northeastern, mainly those family-based farming systems. The area cropped with cowpea covers about 1.2 million of hectares annually. This crop is increasingly damaged by charcoal rot caused by Macrophomina phaseolina that can cause significant reductions in bean yield, ranging from 10 to $100 \%$, depending on the cultivar planted and the planting season. M. phaseolina is a phytopathogenic fungus with origin in the soil and seed, belonging to the family Botryosphaeriaceae. It is one of the most destructive plant pathogens causing diseases in many crop plants, including cotton, soybean, potato and cowpea, among others (Leyva-Mir et al., 2015). The fungus has a worldwide distribution, but is regarded as economically more important in subtropical and tropical countries (Oyewole et al., 2017). The disease is most damaging in areas of unreliable rainfall and high temperature, like the semi-arid region of Brazil. Several efforts have been made to divide the isolates of M. phaseolina into subspecies or subgroups; however, this has been difficult due to extreme variation intraspecific in morphology and pathogenicity. Access to genetic variability of fungi allows evaluating intra and interspecific phylogenetic relationships, the identification of races and pathogenic isolates and can be done using molecular markers, which can be used as an auxiliary tool to classical taxonomy and in the disease control strategies (Nozaki et al., 2006). Molecular approaches based on sequence analysis of nucleic 
acids has been used with success in the characterization of M. phaseolina (Jana et al., 2003; Sarr et al., 2014; Leyva-Mir et al., 2015; Salahlou et al., 2016).

Amongst the different PCR methods, those involving single primers are more frequently used due to their simplicity, robustness and reliability. The ISSR (Inter Simple Sequence Repeats) is a PCR based DNA diagnostic assay involving PCR amplification of genomic DNA segments. ISSR markers represent mostly noncoding regions of the genome flanked by microsatellites (Zietkiewicz et al., 1992). This marker reveals a much larger number of polymorphic fragments per primer also do not require prior knowledge of DNA sequence for primer design (Singh et al., 2016). Some of the major areas of the application of ISSR are in genomic fingerprinting, genetic diversity and phylogenetic analysis. Thus, this study was performed in order to reveal the genetic polymorphism of M. phaseolina populations collected from cowpea genotypes growing in semi-arid regions of Brazil using ISSR markers.

\section{Methods}

\subsection{Fungal Isolates}

Isolates of M. phaseolina were obtained from cowpea plants displaying typical symptoms and signs of charcoal rot from areas of cultivation of this plant in Brazil semi-arid region. Small sections $(0.5 \mathrm{~cm})$ were excised of the stems and leaves. The tissues were surface disinfested with $70 \%$ ethanol for 30 seconds, $1.5 \%$ sodium hypochlorite for 5 minutes and three washes in sterile water. Then the tissues were dried on sterile filter paper, transferred to Petri dishes containing PDA (Potato-Dextrose-Agar) medium, supplemented with Chloramphenicol $(100 \mu \mathrm{g} / \mathrm{ml})$ and incubated at room temperature $\left(25 \pm 2{ }^{\circ} \mathrm{C}\right)$. After growth, the colonies were obtained by the hyphal tip technique.

\subsection{DNA Isolation, Amplification and Cluster Analysis}

Genomic DNA was extracted from fresh mycelia according to the procedure of Samarrai and Shimid (2000). The quantity and quality of DNA samples were determined by electrophoresis, and were stored at $-20{ }^{\circ} \mathrm{C}$ until used. After initial tests with 38 primers, University of British Columbia (UBC ISSR), the most polymorphic were selected (Table 1) and used to amplify the genomic DNA. The PCR reaction was performed in a $25-\mu \mathrm{L}$ reaction volume containing 15-20 ng of DNA template, $10 \mathrm{mM}$ Tris- $\mathrm{HCl}, \mathrm{pH} 8.0), 2 \mathrm{mM} \mathrm{MgCl}_{2}, 100 \mathrm{mM}$ each of four deoxyribonucleotide triphosphate (dNTPs), $1 \mathrm{mM}$ primer, 1.5 units of Taq polymerase (Life Technologies). PCR amplification was carried out with the thermocycler (MJ Research, Inc. PTC 100 (Watetown, USA) in follows conditions: $94{ }^{\circ} \mathrm{C}$ for $5 \mathrm{~min}, 94{ }^{\circ} \mathrm{C}$ for $30 \mathrm{~s}$ followed by $30-35$ cycles at $50-55^{\circ} \mathrm{C}$, primer extension at $72{ }^{\circ} \mathrm{C}$ for 2 min, and a final primer extension at $72{ }^{\circ} \mathrm{C}$ for $5 \mathrm{~min}$. The amplified DNA fragments were separated by electrophoresis in 2.0\% agarose gel and stained with SyBr Gold (Molecular Probe). The ISSR marker bands visualized in the gels were computed as presence (1) or absence (0). The results of these data generated a binary matrix that was analyzed using the FreeTree version 0.9.1.50 (Pavlicek et al., 1999) to determine the similarities among individuals. Similarities were estimated using Jaccard's (J) coefficient. Clustering analysis was performed using TreeView software programs version 1.6.6 (Page et al., 2001) by the unweighted pair-group method using arithmetic averages (UPGMA).

Table 1. Primer names and sequences, annealing temperature and degree of polymorphism of amplified DNA of M. phaseolina isolates using each of the seven primers of ISSR

\begin{tabular}{llllll}
\hline Primers UBC & $\begin{array}{l}\text { Sequence } \\
\left(\mathbf{5}^{\prime} \rightarrow \mathbf{3}^{\prime}\right)\end{array}$ & Number of bands & $\begin{array}{l}\text { Number of } \\
\text { polymorphics bands }\end{array}$ & Polymorphism $(\%)$ & $\begin{array}{l}\text { Annealing } \\
\text { temperature }\left({ }^{\circ} \mathbf{C}\right)\end{array}$ \\
\hline 808 & $(\mathrm{AG})_{8} \mathrm{C}$ & 18 & 17 & 94 & 50 \\
809 & $(\mathrm{AG})_{8} \mathrm{G}$ & 12 & 5 & 41 & 52 \\
810 & $(\mathrm{GA})_{8} \mathrm{~T}$ & 17 & 15 & 90 & 50 \\
841 & $(\mathrm{GA})_{8} \mathrm{YC}$ & 12 & 8 & 67 & 52 \\
868 & $(\mathrm{GAA})_{6}$ & 10 & 7 & 70 & 50 \\
873 & $(\mathrm{GACA})_{4}$ & 10 & 8 & 80 & 50 \\
887 & $\mathrm{DVD}(\mathrm{TC}) 7$ & 9 & 6 & 67 & 55 \\
\hdashline Total & - & 88 & 66 & 75 & - \\
\hline
\end{tabular}




\section{Results and Discussion}

The polymerase chain reaction (PCR) based on molecular markers such as inter-simple sequence repeats (ISSR) have being extensively used for rapidly assessing variation within and among species. Several studies have shown a high level of polymorphism in M. phaseolina (Mahdizadeh et al., 2011, 2012; Saar et al., 2014; Salahlou et al., 2016). These studies have demonstrated that high genetic diversity of this fungal species is reflected not only in isolates from distinct hosts but also within isolates collected from a single host or geographical origin.

In this study, fifty-one Macrophomina isolates were obtained from cowpea genotypes in Brazil's semi-arid region. The seven ISSR primers produced 88 scorable bands, of which $66(75 \%)$ were polymorphic. The fragments size ranged 350 to $2200 \mathrm{bp}$. The number of amplicons produced by different primers ranged from 9 to 18 with an average of 12.5 amplicons per primer. The level of polymorphism ranged to $41 \%$ to $94 \%$. The maximum number of 18 amplicons was generated by the primer UBC 808 whereas, the UBC 887 primer generated a minimum number of 9 amplicons. The details of markers amplified by the 7 ISSR primers among the 51 isolates are given in (Table 1). Mahdizadeh et al. (2012) evaluated genetic diversity of $M$. phaseolina isolates in Sesame (Sesamum indicum L.). They used six ISSR primers that amplified fragments with size ranged from 250 to $3,300 \mathrm{bp}$. A total of 55 bands were observed, with 9.17 bands per primer. Thirty-eight out of 55 bands (66.61\%) were polymorphic. Five primers previously used by Mahdizadeh et al. were also used by Salahlou et al. (2016) to study populations of M. phaseolina. These primers produced 105 scorable bands, of which 85 (77.11\%) were polymorphic. Our results are in corroboration with the above findings. Although the primers used in our study were different, polymorphism level values were very close to previous reports.

The binary data from the polymorphic primers were used for computing Jaccard's similarity indices. Among the 51 M. phaseolina isolates, the highest similarity index (0.9) was observed between the isolates isol22 and isol35; and the lowest similarity index (0.2) was observed between isol37 and isol46 isolates. Dendrogram derived from an UPGMA cluster analysis is shown in Figure 1. The first main group comprises the majority of isolates. In this group, most of the isolates showed similarity indices around 0.52 . The second main group contains two isolates, isol46 and isol47. These isolates presented similarity index of 0.7 each other, and high divergence with the group 1. Being the lowest indices of similarity observed among group 2 and the isolates, isol12, isol26 and isol37 (group 1). Taken together, these results at least suggest that there may be a difference between groups 1 and 2 , into the molecular basis. In spite of the genus Macrophomina contains only one species, its broad host specificity and geographical distribution, suggests that the pathogen is quite heterogeneous. This variability is observed in isolates obtained from both a single plant and a single host species (Babu et al., 2011). Therefore, genetic characterization of this fungus is of importance for the effective disease management. Our results revealed that the pattern of bands generated by ISSR markers were useful to differenciate M. phaseolina isolates from Brazil's semi-arid region. This may allow the development of genus specific DNA markers for Macrophomina that will facilitate identification of this pathogen, contributing to epidemiological studies. 


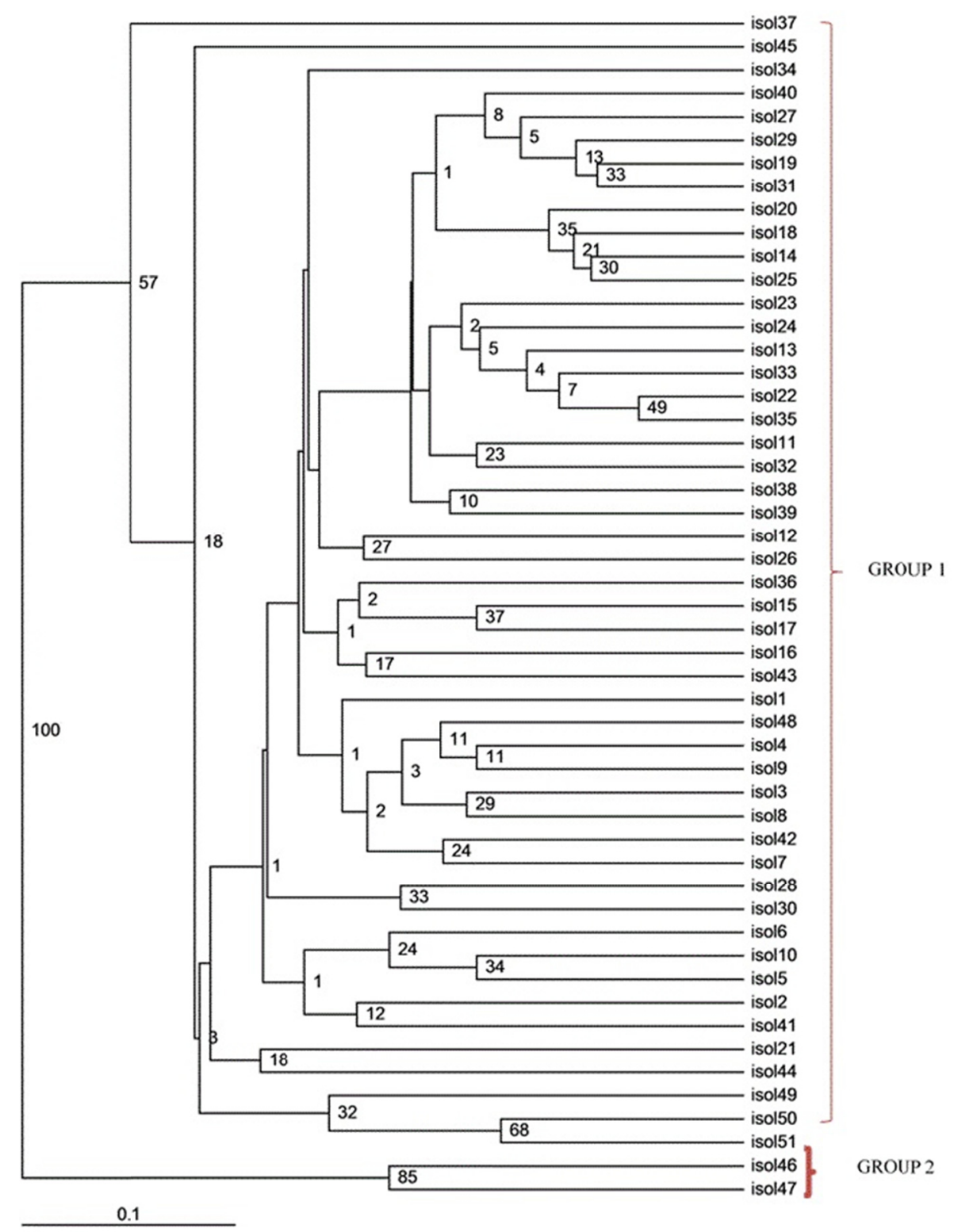

Figure 1. UPGMA dendrogram based on Jaccard's (J) coefficient showing the relationships among 51 of $M$. phaseolina isolates from cowpea using ISSR markers. Group 1 contains most of isolates; Group 2 contains two isolates, isol46 and isol47. Numbers indicate frequency of each branch from bootstrap analyses of 1,000 replicates. Bars present 0.1 substitutions per nucleotide position

\section{References}

Al-Samarrai, T. H., \& Schmid, J. (2000). A simple method for extraction of fungal genomic DNA. Letters in Applied Microbiology, 30(1), 53-6. https://doi.org/10.1046/j.1472-765x.2000.00664.x

Babu, B. K., Mesapogu, S., Sharma, A., Somasani, S. R., \& Arora, D. K. (2011). Quantitative real-time PCR assay for rapid detection of plant and human pathogenic Macrophomina phaseolina from field and environmental samples. Mycologia, 103, 466-473. https://doi.org/10.3852/10-181

Chaudhary, H., Singh, D. K., Marla, S. S., \& Chauhan, V. B. S. (2011). Genetic diversity among cultivated and wild germplasm of cucumber based on RAPD analysis. Indian Journal of Horticulture, 68, 197-200.

FAO. (2016). Crops: Cowpeas, Dry. FAOSTAT. Retrieved August 15, 2016, from http://faostat.fao.org/site/ 567/DesktopDefault.aspx?PageID=567\#ancor. 
Jana, T., Sharma, T. R., Prasad, R. D., \& Arora, D. K. (2003). Molecular characterization of Macrophomina phaseolina and Fusarium species by a single primer RAPD technique. Microbiological Research, 158, 249-257. https://doi.org/10.1078/0944-5013-00198

Leyva-Mir, S. G., Velázquez-Martínez, G. C., Tlapal-Bolaños, B., Tovar-Pedraza, J. M., Rosas-Saitoy, G. H., \& Alvarado-Gómez, O. G. (2015). Morphological and Molecular Characterization of Isolates of Macrophomina Phaseolina Associated with Sugarcane in Mexico. Revista Argentina de Microbiologia, 47(2), 143-147. https://doi.org/10.1016/j.ram.2015.03.003

Mahdizadeh, V., Safaie, N., \& Goltapeh, E. M. (2011). Diversity of Macrophomina phaseolina Based on Morphological and Genotypic Characteristics in Iran. Plant Pathology Journal, 27(2), 128-137. https://doi.org/10.5423/PPJ.2011.27.2.128

Mahdizadeh, V., Safaie, N., \& Goltapeh, E. M. (2012). Genetic diversity of Sesame isolates of Macrophomina phaseolina using RAPD and ISSR markers. Trakia Journal of Sciences, 10(2), 65-74. Retrieved from http://www.uni-sz.bg

Marinho, R. C. N., Ferreira, L. V. M., Silva, A. F., Martins, L. M. V., Nóbrega, R. S. A., \& Fernandes-Júnior, P. I. (2017). Symbiotic and agronomic efficiency of new cowpea rhizobia from Brazilian Semi-Arid. Bragantia, 76(2), 273-281. https://doi.org/10.1590/1678-4499.003

Nozaki, M. H., Camargo, M., Lemos, E. G. M., Aukar, A. P. A., \& Barreto, M. (2006). Caracterização molecular através da técnica fAFLP de isolados de Diaporthe citri. Summa Phytopathologica, 32(2), 147-150. https://doi.org/10.1590/S0100-54052006000200008

Oyewole, B. O., Olawuyi, O. J., Odebode, A. C., \& Abiala, M. A. (2017). Influence of Arbuscular mycorrhiza fungi (AMF) on drought tolerance and charcoal rot disease of cowpea. Biotechnology Reports, 14, 8-15. https://doi.org/10.1016/j.btre.2017.02.004

Page, R. D. M. (2001). TreeView (Win32), Ver. 1.6.6. Retrieved from http:// http://treeview.software.informer.com

Pavlicek, A., Hrda, S., \& Flegr, J. (1999). FreeTree: Freeware Program for Construction of Phylogenetic Trees on the Basis of Distance Data and Bootstrap/Jackknife Analysis of the Tree Robustness. Application in the RAPD Analysis of Genus Frenkelia. Folia Biologia (Praha), 45, 97-99. Retrieved from http://www.natur.cuni.cz/flegr/programs/+++freetree

Salahlou, R., Safaie, N., \& Shams-Bakhsh, M. (2016). Genetic Diversity of Macrophomina phaseolina Populations, the Causal Agent of Sesame Charcoal Rot Using Inter-Simple Sequence Repeat Markers. Journal of Agricultural Science and Technology, 18, 277-287. Retrieved from http://jast.modares.ac.ir/ article_13988_5346.html

Sarr, M. P., Ndiaye, M'Baye., Groenewald, J. Z., \& Crous, P. W. (2014). Genetic diversity in Macrophomina phaseolina, the causal agent of charcoal rot. Phytopathologia Mediterranea, 53(2), 250-268.

Singh, D. K., Tewari, R., Singh, N. K., \& Singh, S. S. (2016). Genetic Diversity Cucumber Using Inter Simple Sequence Repeats (ISSR). Transcriptomics, 4(1), 1-4. https://doi.org/10.4172/2329-8936.1000129

Zietkiewicz, E., Labuda, M., Sinnett, D., Glorieux, F. H., \& Labuda, D. (1992). Linkage mapping by simultaneous screening of multiple loci using ALU oligonucleotidedirected PCR. Proceedings of the National Academic Science, 89, 8448-8451. https://doi.org/10.1073/pnas.89.18.8448

\section{Copyrights}

Copyright for this article is retained by the author(s), with first publication rights granted to the journal.

This is an open-access article distributed under the terms and conditions of the Creative Commons Attribution license (http://creativecommons.org/licenses/by/4.0/). 